keener enterprise of our industrialists and the higher skill of our workmen. Experience of the War has shown that Great Britain is second to none in the fields of scientific discovery and invention, and industrialists have shown that they are capable of translating the results of research rapidly and efficiently into products required for the successful prosecution of the War. This high quality of research is one of the surest grounds for confidence in our ability to meet successfully the difficult times that lie ahead.

\section{Taxation and Research}

REFERENCE has been made in various recent reports on scientific research and industry to the financial aspect in its relation to taxation. Thus the London Chamber of Commerce report (see Nature, March 11, p. 294) advocates that expenditure on research should be chargeable on revenue. The matter has also been taken up by the Parliamentary and Scientific Committee, which has prepared a memorandum on the subject. This memorandum urges that the Government, in considering its taxation policy, should look to the prospect of benefiting from higher income tax returns when industry, as a result of the development, through research, of new processes and products, is made more profitable. The recommendations, however, are intended to afford a basis for discussion rather than to represent rigid and final views, and in particular the Committee wishes to learn the opinion of the revenue authorities on the practical reactions of its proposals. In general, it is recommended that the law relating to the taxation of profits should be amended so as to recognize the principle that all expenses incurred on research and development are allowable as deductions from taxable profits, with the corollary that receipts from a lease or sale of discoveries should be brought into taxable profits. It is also suggested that an allowance should be made for taxation purposes of a fixed percentage of any capital assets which have been provided solely for research purposes. The Committee also supports suggestions made by representative trade bodies to the Inland Revenue Committee regarding the amortization of business premises and machinery generally. Depreciation rates should be increased so as to include obsolescence, which has become a more important factor than wear and tear.

\section{British Radio Research Institute}

THE British Institution of Radio Engineers recommends the formation of a British Radio Research Institute, the functions of which would be the pursuit of basic research of the type that has hitherto suffered restriction owing to its high cost, absence of obvious or immediate practical applications, or the poor prospect of early financial returns. The institute should be financed by industry supplemented by a Government grant of at least equal amount. The work of the institute should be directed by a board representing Governmental authorities, the B.B.C. and the Services, the industry, the British Institution of Radio Engineers, the associated professional institutions and the universities of the Empire. In addition to a permanent scientific staff, the assistance and engagement of extra-mural workers should be arranged in co-operation with industry and the universities.

The advantages to be derived from the proposals are that the advancement of radio and electronic sciences would be freed from the limitations of restricted finance, duplication of original research work, spasmodic trade fluctuations, etc. Competitive private enterprise would be stimulated and the intake of high-grade technical personnel increased. It would remain with private enterprise to develop the practical and industrial applications of the scientific results flowing from the research institute. The pre-war hiatus between industry, the Government and scientific workers would be effectively bridged by the proposed governing board. New knowledge, carrying with it the possibility of new industries, would be continuously sought and be available for the free use of manufacturers to develop practical applications of the scientific principles. The necessity for private research departments would not be reduced; but the availability of undeveloped basic knowledge would give such departments a far greater opportunity for returning a dividend. The application of radio technique to fields other than broadcasting is capable of considerable development, and therefore the potential absorption of labour is considerable.

On the financial side, the contribution of industry to research associations was increasing before the War, and support is now being given to the principle of larger contributions being made in the future. Assuming the turnover to be only $£ 20$ million for the radio industry, an allocation of 0.25 per cent would give, with Government assistance, an income comparable with that of other research associations. If subscribing membership is open to all British industrial undertakings in the British Commonwealth which produce, manufacture or use electronic equipment, the income of the research institute would be comparable with the support given to any other association, while at the same time making the field of research inexhaustible. During the War, radio has graduated into a highly important industry. In the post-war era it should be supplying capital goods on a scale equal to many of the older industries; not only should the range and quality of its consumer goods be very different from anything known before, but also essential instruments and devices for other industries must be provided if British scientific and industrial progress is to be maintained. For all this development co-operative research is essential. It is strongly advocated by the Institution that opportunity for participation in the work of the research institute shall be provided for all countries in the British Commonwealth. Such collaboration in research will materially aid development of communications and the prosperity of the entire Empire.

\section{Fuel for Household Use}

ON February $18 \mathrm{Mr}$. J. G. Bennett, addressing the Fuel Luncheon Club in London on "The Future of Coal for Small-Scale Uses", compared raw coal, town's gas and electricity for household space heating. The comparison was based on heat costs incurred in production and distribution and the efficiency in use of gas and electricity when these are produced from cotl. The results for all three, with appliances of current type, turned out to be identical -16 per cent of the heating value of the coal. Developments anticipated in appliances were estimated to increase these figures to 45 per cent for coal burnt in open fires, 24 per cent for gas and 33 per cent for electricity. Some may read into these figures the implication that no fuel-saving can be expected from the processing of coal before use. It should, however, be recalled that coal-less countries import 
large quantities of coal for carbonization to produce gas and coke. It is unlikely that they are unanimously thriftless. Attention should be paid to the difference in the method of calculation. In the case of coal and electric fires, the resulting heat is usually a product of the raw coal. Gas, however, is derived from the volatile matter only, which is not more than one third of the whole of the coal. Then nearly the whole of the heat cost of processing is charged against this gas, and the end efficiency figure is reduced to one sixth. Even then, the efficiency figure is not less than the figure given for coal and electricity. Unlike, but over and above these, there remains some halfton of coke available for domestic and industrial uses for which raw coal is unsuitable. At the moment, the Ministry of Fuel and Power is taking advantage of this reserve.

Mr. Bennett mentioned that the financial importance of the by-products of coal is apt to be exaggerated. This is true, but their usefulness should not be depreciated. Tar components amount to about 6 per cent by weight. They are, however, components of smoke and soot. As such, they are better recovered fit for uses which would otherwise necessitate importation of bituminous material. In this connexion it is interesting to take note of the views put forward by Harold Moore, only a fortnight earlier, in a paper read before the Institute of Fuel. This was a plea for a plan to meet the national needs for liquid fuels and organic chemicals. In addition to the development of home refining of petroleum, he considers that the most important feature of the plan should be the extension of coal carbonization. To promote this, he even advocates legislation against burning raw bituminous coal.

\section{Basic English}

Mr. Churchill announced in the House of Commons on March 9 that the Committee of Ministers on Basic English has submitted a report which has been approved in principle by the Government. So far as concerns the use of Basic English as an auxiliary international language, the Government is impressed with the great advantages which would ensue from its development, not in substitution for established literary languages, but as a supplement thereto, and is taking steps to develop its use as an auxiliary international and administrative language. The British Council will include the teaching of Basic English in addition to its more general activities in promoting the teaching of English for its own sake. Diplomatic and commercial representatives in foreign countries will be asked to do all they can to encourage the spread of Basic English as an auxiliary language. It is also intended to arrange for the translation into Basic English of a wider range than is at present available of literature, scientific, technical and general, both from ordinary English and from foreign languages, and also to increase the supply of manuals of instruction in Basic English. Some Colonial Governments will be invited to issue handbooks in Basic English for Colonial peoples on agriculture, hygiene, etc., and to use it in some administrative instructions. The British Broadcasting Corporation has been asked to consider the use and teaching of Basic English in appropriate oversea programmes. Primary responsibility for questions affecting Basic English and for giving effect to the recommendations of the Committee of Ministers will rest with the Foreign Office through the British Council.

\section{Technology of Tea}

DR. E. B. HUGHES, past-president of the Society of Public Analysts and Other Analytical Chemists, was unable to deliver his presidential address when he retired from office last year. Accordingly he delivered it after the annual general meeting of the Society held on March I, speaking on "The Technology of Tea". Tea-growing areas are not now confined to Asia ; the necessary tropical or subtropical conditions exist elsewhere and tea is now grown extensively in Africa, even so far south as Natal, and also in Russia. In the production of black tea, as distinct from green tea, the main processes are withering, rolling, fermentation and final drying. Withering is a partial natural drying process at as cool a temperature as possible. It dries the leaves to a condition in which they can be rolled and twisted by mechanical action simulating rotatory rubbing between the hands; this damages the cells, whereupon, possibly as a result of 'disorganized respiration', oxidase of the leaf brings about 'fermentation'. 'This so-called fermentation is mainly oxidation of polyphenols of the leaf to quinone compounds, which readily produce reddish, copper-coloured condensation products. The polyphenols of the leaf are the so-called tea tannins, but they are not tannins in the ordinary sense, as they are not able to convert hide into leather. The rate of 'fermentation' is highly important; if too rapid, it gives inferior products, and the greater rate of fermentation, combined with lower quality of leaf grown in hot humid conditions, produces a commoner quality of tea. Indeed, the differences in quality and character between teas from different areas are due mainly to differences in geographical and climatic conditions, rather than to varietal differences in the plants grown. Changes in climatic conditions in the same area may produce much choicer tea at one time than a month earlier or later. It is the practice of blending, dependent on the remarkable skill of the tea taster, that enables the consumer to be supplied with brands of unchanging character. Most good teas, as supplied to the consumer, are blends of more than a dozen lots. Green tea is not subjected to 'fermentation', the enzyme activity being destroyed by heating the leaf (steaming) as soon as possible after plucking, after which the leaf is rolled and 'fired'.

\section{Timber-drying Kilns}

Leaflet No. 30 (August 1943) issued by the Forest Products Research Iaboratory, under the auspices of the Department of Scientific and Industrial Research, is on "Observations on the Design of Timber-drying Kilns". The leaflet, which does not pretend to deal in detail with design and construction, may be consulted for the information given on the size of kiln, double-stack pattern, single-stack patterns, heating systems, control instruments, and loading and unloading facilities. It is pointed out that in a welldesigned timber-drying kiln provision must be made for $(a)$ adequate and uniform air circulation between the rows of timber, $(b)$ control of the humidity of the air, and (c) control of the air temperature. It is a generally accepted fact that except for a very limited type of drying operation, adequate air movement cannot be obtained except by means of fans, and that as a medium for heating and humidifying the air, steam can scarcely be rivalled. The practice of placing the heating elements and fans above the pile of timber is now fairly common in kiln design, 